\title{
GAMBARAN FAKTOR RISIKO PADA PENDERITA STROKE ISKEMIK YANG DIRAWAT INAP NEUROLOGI RSUP PROF. DR. R. D. KANDOU MANADO PERIODE JULI 2012 - JUNI 2013
}

\author{
${ }^{1}$ Glen Y. C. R. Kabi \\ ${ }^{2}$ Rizal Tumewah \\ ${ }^{2}$ Mieke A. H. N. Kembuan \\ ${ }^{1}$ Kandidat Skripsi Fakultas Kedokteran Universitas Sam Ratulangi Manado \\ ${ }^{2}$ Bagian Neurologi Fakultas Kedokteran Universitas Sam Ratulangi \\ Email: kabz_bee@yahoo.com
}

\begin{abstract}
Ischemic stroke is a clinical sign of dysfunction or brain tissue damage caused by lack of blood flow to the brain that disrupts the need for blood and oxygen to the brain. WHO defines stroke as a rapidly developing clinical signs of focal brain due to interference (or global) with symptoms - that last for 24 hours or more- and can cause death without any other obvious cause other than vascular. This study aimed to obtain an overview of risk factors in ischemic stroke patients in the Inpatient Neurology Department of Prof. Dr. R. D. Kandou Hospital Manado period July 2012 - June 2013. Data were taken by collecting data of ischemic stroke patients medical records. There were 60 patients during that period. Patients affected by stroke were aged between 51 - 65 years and had histories of hypertension.
\end{abstract}

Keywords: risk factors, ischemic stroke.

\begin{abstract}
Abstrak: Stroke iskemik adalah tanda klinis disfungsi atau kerusakan jaringan otak yang disebabkan kurangnya aliran darah ke otak sehingga mengganggu kebutuhan darah dan oksigen di otak. WHO mendefiniskan stroke merupakan suatu tanda klinis yang berkembang cepat akibat gangguan otak fokal (atau global) dengan gejala - gejala yang berlangsung selama 24 jam atau lebih dan dapat menyebabkan kematian tanpa adanya penyebab lain yang jelas selain vaskuler. Penelitian ini bertujuan untuk mendapatkan gambaran tentang faktor resiko pada pasien stroke iskemik di rawat inap Neurologi RSUP Prof. Dr. R. D. Kandou Manado periode Juli 2012 - Juni 2013. Penelitian dilakukan dengan cara mengumpulkan data pasien yang terkena stroke iskemik di bagian rekam medik RSUP Prof. Dr. R. D. Kandou Manado. Didapatkan 60 pasiem selama periode Juli 2012 - Juni 2013. Berdasarkan hasil yang didapat maka disimpulkan bahwa pasien yang sering terkena stroke adalah pasien yang berumur antara 51-65 tahun, dan pasien yang memiliki riwayat hipertensi.
\end{abstract}

Kata kunci: faktor risiko, stroke iskemik

Setiap tahunnya ada sekitar 5,8 juta orang yang meninggal karena stroke dan duasepertiga dari semua kematian akibat stroke terjadi di negara-negara berkembang. Di Amerika Serikat didapatkan 700.000 orang mengalami stroke baru atau berulang tiap tahunnya. ${ }^{1,2}$ Di Indonesia, prevalensi stroke mencapai angka 8,3 per 1.000 penduduk.
Daerah yang memiliki prevalensi stroke tertinggi adalah Nanggroe Aceh Darussalam (16,6 per 1.000 penduduk) dan yang terendah adalah Papua (3,8 per 1.000 penduduk). Menurut Riskesdas tahun 2008, stroke menempati urutan pertama sebagai penyebab kematian utama semua usia di Indonesia. $^{3}$ 
Stroke merupakan penyakit multifaktorial dengan berbagai jenis penyebab yang disertai manifestasi klinis mayor dan penyebab utama terjadinya kecacatan dan kematian di negara - negara berkembang. ${ }^{4}$ WHO mendefenisikan stroke merupakan suatu tanda klinis yang berkembang cepat akibat gangguan otak fokal (atau global) dengan gejala - gejala yang berlangsung selama 24 jam atau lebih dan dapat menyebabkan kematian tanpa adanya penyebab lain yang jelas selain vaskuler. ${ }^{5}$

Menurut Davenport dan Dennis, secara garis besar stroke dapat dibagi menjadi dua bagian yaitu stroke iskemik dan stroke hemoragik. Di negara barat dari seluruh penderita stroke yang terdata, $80 \%$ merupakan jenis stroke iskemik sementara sisanya merupakan jenis stroke hemoragik. Stroke iskemik adalah tanda klinis disfungsi atau kerusakan jaringan otak yang disebabkan kurangnya aliran darah ke otak sehingga mengganggu kebutuhan darah dan oksigen di otak. ${ }^{6}$

Faktor risiko yang memicu tingginya angka kejadian stroke iskemik adalah faktor yang tidak dapat dimodifikasi (nonmodifiable risk factors) seperti usia, ras, gender, genetik, dan riwayat Transient Ischemic Attack atau stroke sebelumnya. Sedangkan faktor yang dapat dimodifikasi (modifiable risk factors) berupa hipertensi, merokok, penyakit jantung, diabetes, obesitas, penggunaan oral kontrasepsi, alkohol, hiperkolesterolemia. Hipertensi adalah masalah yang sering dijumpai pada pasien stroke, dan menetap setelah serangan stroke. ${ }^{7}$

Identifikasi faktor risiko stroke sangat penting untuk mengendalikan kejadian stroke di suatu negara. Oleh karena itu, berdasarkan identifikasi faktor risiko tersebut maka dapat dilakukan tindakan pencegahan dan penanggulangan penyakit stroke, terutama untuk menurunkan angka kejadian stroke iskemik.

\section{METODE PENELITIAN}

Penelitian ini bersifat deskriptif dengan metode retrospektif. Penelitian dilaksanakan di bagian rekam medik RSUP Prof. Dr. R. D. Kandou Manado pada bulan November hingga bulan Desember 2013. Sampel penelitian adalah pasien stroke iskemik yang dirawat inap di RSUP Prof. Dr. R. D. Kandou Manado dengan kriteria inklusi yaitu pasien stroke iskemik yang berjenis kelamin laki-laki maupun perempuan dan pada rekam medis terdapat hasil laboratorium, kriteria eksklusi sampel pada penelitian ini jika ditemukan data pada rekam medik kurang memadai atau tidak lengkap.

\section{HASIL PENELITIAN}

Didapatkan 60 orang yang memenuhi kriteria inklusi. Pada Tabel 1 diperlihatkan distirbusi frekuensi jenis kelamin stroke iskemik. Jenis kelamin terbanyak laki-laki yaitu 33 orang (55\%) dan jenis kelamin perempuan 27 orang (45\%).

Tabel 1. Distribusi Frekuensi Jenis Kelamin Pasien Stroke Iskemik

\begin{tabular}{ccc}
\hline Jenis Kelamin & Jumlah & Persentase \\
\hline Laki-laki & 33 & $55 \%$ \\
Perempuan & 27 & $45 \%$ \\
\hline Total & 60 & $100 \%$ \\
\hline
\end{tabular}

Pada Tabel 2 diperlihatkan distirbusi frekuensi umur pasien stroke iskemik. Kelompok umur terbanyak 51-65 tahun dan kelompok umur paling sedikit $<35$ tahun.

Tabel 2. Distribusi Frekuensi Umur Pasien Stroke Iskemik

\begin{tabular}{ccc}
\hline Umur & Jumlah & $\mathbf{\%}$ \\
\hline <35 Tahun & 9 & 15 \\
35 - 50 Tahun & 15 & 25 \\
51 - 65 Tahun & 25 & 41,6 \\
$>$ 65 Tahun & 11 & 18,4 \\
\hline Total & 60 & 100 \\
\hline
\end{tabular}

Tabel 3 memperlihatkan distribusi frekuensi pekerjaan pasien stroke iskemik dimana pekerjaan terbanyak IRT sebanyak 18 orang (30\%) dan jumlah terendah tidak bekerja sebanyak 6 orang (10\%). 
Tabel 3. Distribusi Pekerjaan Pasien Stroke Iskemik

\begin{tabular}{ccc}
\hline Pekerjaan & Jumlah & $\mathbf{\%}$ \\
\hline PNS & 12 & 20 \\
Swasta & 15 & 25 \\
IRT & 18 & 30 \\
Petani & 9 & 15 \\
Tidak Bekerja & 6 & 10 \\
\hline Total & 60 & 100 \\
\hline
\end{tabular}

Pada Tabel 4 didapatkan frekuensi riwayat penyakit keluarga pasien stroke iskemik, jumlah sampel yang memiliki riwayat keluarga adalah 37 orang (61,6\%) dan yang tidak memiliki riwayat keluarga yaitu 23 orang $(38,4 \%)$.

Tabel 4. Distribusi Frekuensi Riwayat Penyakit Keluarga Pasien Stroke Iskemik

\begin{tabular}{ccc}
\hline RPK & Jumlah & \% \\
\hline Ada & 37 & 61,6 \\
Tidak ada & 23 & 38,4 \\
\hline Total & 60 & 100 \\
\hline
\end{tabular}

Dalam Tabel 5 diperlihatkan distribusi frekuensi hipertensi pasien stroke iskemik. Sampel dengan tekanan darah normal sebanyak 7 orang (11,6\%), pre-hipertensi sebanyak 13 orang (23\%), dan hipertensi sebanyak 40 orang $(65,4 \%)$.

Tabel 5. Distribusi Frekuensi Hipertensi Pasien Stroke Iskemik

\begin{tabular}{lcc}
\hline \multicolumn{1}{c}{ Hipertensi } & Jumlah & \% \\
\hline $\begin{array}{l}\text { Normal (sistolik }<129 \text { atau } \\
\text { diastolik }<80 \text { mmHg) }\end{array}$ & 7 & 11,6 \\
$\begin{array}{l}\text { Pre-Hipertensi (sistolik } 120-139 \\
\text { atau diastolik } 80-89 \text { mmHg) }\end{array}$ & 13 & 23 \\
$\begin{array}{l}\text { Hipertensi (sistolik }>140-160 \\
\text { atau diastolik }>90-100 \text { mmHg) }\end{array}$ & 40 & 65,4 \\
\hline \multicolumn{1}{c}{ Total } & 60 & 100 \\
\hline
\end{tabular}

Pada Tabel 6 disajikan informasi berupa distribusi frekuensi penyakit diabetes melitus pasien stroke iskemik. Hasil yang didapat adalah sampel dengan penyakit DM sebanyak 16 orang (26,6\%) dan yang tidak DM sebanyak 44 orang $(73,4 \%)$.
Tabel 6. Distribusi Frekuensi Penyakit Diabetes Mellitus Pasien Stroke Iskemik

\begin{tabular}{ccc}
\hline Diabetes Mellitus & Jumlah & $\mathbf{\%}$ \\
\hline Ada & 16 & 26,6 \\
Tidak Ada & 44 & 73,4 \\
\hline Total & 60 & 100 \\
\hline
\end{tabular}

Pada Tabel 7 ditunjukkan distribusi frekuensi penyakit jantung pasien stroke iskemik. Sampel dengan penyakit jantung adalah sejumlah 8 orang (13\%) dan tidak memiliki penyakit jantung sebanyak 52 orang (87\%).

Tabel 7. Distribusi Frekuensi Penyakit Jantung Pasien Stroke Iskemik

\begin{tabular}{ccc}
\hline Penyakit Jantung & Jumlah & $\mathbf{\%}$ \\
\hline Ada & 8 & 13 \\
Tidak Ada & 52 & 87 \\
\hline Total & 60 & 100 \\
\hline
\end{tabular}

\section{BAHASAN}

Pada Tabel 1 dapat dilihat bahwa pasien stroke iskemik lebih banyak berjenis kelamin laki-laki. Dari 60 pasien stroke iskemik di rawat inap Neurologi di Prof. Dr. R. D. Kandou, sebanyak 33 pasien (55\%) berjenis kelamin laki-laki dan 27 pasien (45\%) berjenis kelamin perempuan. Dari penelitian ini terlihat bahwa kejadian stroke iskemik lebih banyak dialami oleh laki-laki daripada perempuan, Hal ini disebabkan oleh karena perempuan lebih terlindungi dari penyakit jantung dan stroke sampai pertengahan hidupnya akibat hormon esterogen yang dimilikinya.

Dari Tabel 2 berdasarkan distribusi frekuensi umur pasien stroke iskemik dari periode Juli 2012 - Juni 2013, dimana umur dari seorang pasien yang menderita stroke iskemiktersebut berkisar dari $<35$ tahun sampai >65 tahun. 25 pasien (41,6\%) stroke iskemik berumur 51 - 65 tahun, 15 pasien (25\%) berumur 35 - 50 tahun, 11 pasien $(18,4 \%)$ berumur $>65$ tahun, dan 9 pasien (15\%) berumur <35 tahun. Pada dasarnya stroke iskemik dapat terjadi tanpa memandang usia bahkan pada usia muda 
sekalipun bila dilihat dari data hasil penelitian. Akan tetapi pola penyakit stroke iskemik yang cenderung terjadi pada golongan umur yang lebih tua dan sering ditemui di banyak wilayah. Hal ini disebabkan oleh karena penyakit yang terjadi akibat gangguan aliran darah. Seperti kita ketahui, pembuluh darah orang yang lebih tua cenderung mengalami perubahan secara degeneratif dan mulai terlihat hasil dari proses aterosklerosis. Cepat atau lambatnya proses ini yang dapat menjadi pencetus stroke tergantung dari gaya hidup sehat serta perilaku dan pola makan seseorang. ${ }^{8}$

Dari Tabel3 dapat dilihat bahwa dari 60 pasien stroke iskemik di rawat inap Neurologi di Prof. Dr. R. D. Kandou, masing-masing mempunyai beberapa macam pekerjaan. Pekerjaan sebagai pegawai negeri sipil sebanyak 12 pasien (20\%), sebagai swasta sebanyak 15 pasien (25\%), sebagai ibu rumah tangga sebanyak 18 pasien (30\%), sebagai petani sebanyak 9 pasien (15\%), dan yang tidak bekerja/pensiunan sebanyak 6 pasien (10\%). Dari penelitian ini didapatkan proporsi pasien stroke iskemik lebih banyak pada mereka yang bekerja. Hal ini disebabkan karena stres psikologis akibat pekerjaan yang dapat meningkatkan resiko terkena stroke iskemik.

Riwayat penyakit keluarga dalam hasil penelitian ini adalah latar belakang penyakit stroke iskemik atau penyakit lainnya yang merupakan faktor resiko terjadinya stroke (hipertensi, DM, jantung) yang pernah dialami oleh keluarga penderita stroke. Apakah keluarga penderita stroke iskemik ada yang pernah memiliki riwayat penyakit tersebut atau tidak. Berdasarkan Tabel 4 didapatkan dari 60 pasien stroke iskemik di rawat inap Neurologi di Prof. Dr. R. D. Kandou, sebanyak 23 (38,4\%) pasien memiliki riwayat penyakit keluarga. Sedangkan 37 (61,6\%) pasien lainnya tidak memiliki riwayat penyakit keluarga. Hasil ini serupa dengan penelitian lain, dimana pada penelitian di RSCM Jakarta tahun 1997 diketahui bahwa riwayat penyakit keluarga (hipertensi, DM, dan jantung) pada pasien stroke iskemik sebesar $20,5 \%$. Jumlahnya memang lebih sedikit dibandingkan dengan pasien yang tidak memiliki riwayat penyakit keluarga. Hal ini menunjukan bahwa proporsi pasien stroke iskemik yang tidak memiliki riwayat penyakit pada keluarga mereka masih lebih banyak dibandingkan dengan pasien stroke iskemik yang memiliki riwayat penyakit keluarga. Artinya, sebagian besar pasien mendapatkan serangan stroke iskemik pertama kali bukan karena memiliki riwayat penyakit keluarga.

Hipertensi merupakan faktor resiko utama dari penyakit stroke iskemik, baik tekanan sistolik maupun tekanan diastoliknya yang tinggi. Semakin tinggi tekanan darah seseorang, maka semakin besar resiko untuk terkena stroke. Hal ini terlihat juga berdasarkan Tabel 5 dimana sebagian besar pasien stroke iskemik di rawat inap Neurologi di RSUP Prof. Dr. R. D. Kandou memiliki hipertensi yaitu sebanyak 40 pasien (65,4\%), pre-hipertensi sebanyak 13 pasien (23\%), dan yang normal sebanyak 7 pasien $(11,6 \%)$. Dari hasil penelitian ini menunjukan bahwa kejadian stroke iskemik lebih banyak pada orang-orang yang memiliki tekanan darah tinggi, terutama pada golongan hipertensi yang tekanan sistolik $>140-160$ atau diastolik > $90-100 \mathrm{mmHg}$. Hal ini menunjukan bahwa sebagian besar pasien mendapatkan serangan stroke pertama kali memiliki status hipertensi atau tekanan darah yang tinggi. Hipertensi memang merupakan faktor resiko yang kuat untuk terjadinya stroke. Hal ini disebabkan oleh hipertensi dapat menipiskan dinding pembuluh darah dan merusak bagian dalam pembuluh darah yang mendorong terbentuknya plak aterosklerosis sehingga memudahkan terjadinya penyumbatan atau pendarahan otak. ${ }^{9}$

Tabel 6 menunjukkan bahwa dari 60 pasien stroke iskemik di rawat inap Neurologi di Prof. Dr. R. D. Kandou, sebanyak 16 pasien (26,6\%) dengan riwayat DM dan $44(73,4 \%)$ pasien yang tidak 
memiliki riwayat DM.

Diabetes mellitus merupakan keadaaan hiperglikemia yang kronis, disebabkan oleh berbagai faktor lingkungan dan faktor genetik. Dari berbagai penelitian ditemukan bahwa orang dengan DM memiliki resiko lebih besar untuk terkena stroke iskemik daripada orang yang tidak memiliki riwayat DM, karena dapat memicu terjadinya aterosklerosis lebih cepat dibandingkan dengan orang yang tidak menderita DM. Akan tetapi, pada penelitian ini menunjukan bahwa proporsi pasien stroke iskemik dengan DM lebih kecil dibandingkan stroke iskemik tanpa DM. Hal ini menunjukan bahwa proporsi orang terkena serangan stroke iskemik akibat penyakit DM tidak banyak, artinya sebagian besar pasien mendapatkan serangan stroke iskemik pertama kali bukan karena memiliki penyakit DM. ${ }^{10}$

Dari Tabel 7 diketahui sebanyak 52 pasien $(87 \%)$ tidak memiliki riwayat penyakit jantung dan sebanyak 8 pasien (13\%) tidak memiliki riwayat penyakit jantung. Hal ini menunjukan bahwa proporsi pasien stroke iskemik dengan penyakit jantung lebih sedikit dibandingkan dengan pasien stroke iskemik yang tidak memiliki penyakit jantung. Penyakit jantung merupakan faktor resiko stroke, terutama pada stroke iskemik. Akan tetapi, banyak penelitian di rumah sakit yang menunjukan bahwa proporsi pasien stroke iskemik dengan penyakit jantung lebih kecil dibandingkan dengan pasien tanpa penyakit jantung. Hal ini menunjukan bahwa proporsi orang terkena serangan stroke iskemik akibat penyakit jantung tidak banyak, artinya sebagian besar pasien mendapatkan serangan stroke iskemik pertama kali bukan karena memiliki penyakit jantung. ${ }^{10}$

\section{SIMPULAN}

Berdasarkan hasil penelitian deskriptif retrospektif yang dilakukan di bagian Neurologi di RSUP Prof. Dr. R. D. Kandou periode Juli 2012 - Juni 2013 dapat ditarik kesimpulan bahwa:
1. Jumlah pasien laki-laki yang menderita stroke iskemik lebih banyak daripada perempuan.

2. Yang sering terkena stroke iskemik ialah laki-laki, dengan frekuensi umur tersering 51-65 tahun.

3. Yang sering terkena stroke iskemik ialah pasien yang menderita hipertensi dan yang bekerja.

\section{DAFTAR PUSTAKA}

1. World Health Organization, 2010-b. Global Burden of Stroke. Available from: http://www.who.int/cardiovascular_dis eases/en/cvd_atlas_15_burden_stroke. pdf [Accessed 2 October 2013].

2. Xu C. Minor Allele C of Chromosome 1p32 Single Nucleotide Polymorphism rs11206510 Confers Risk of Ischemic Stroke in Chinese Han Population. J Stroke, 2010;41:1587-1592.

3. Hasnawati Sugito, Purwanto $H$, dan Brahim R.Profil Kesehatan Indonesia 2008. Dalam: Pusat Data dan Informasi Departemen Kesehatan Republik Indonesia, 2009. [cited 5 Januari 2012] Available from: http://www.depkes.go.id/resources/do wnload/pusdatin/profil-kesehatanindonesia/profil-kesehatan-indonesia2008.pdf

4. Saidi S, Mahjoub T, and Almawi W Y. Aldosterone Syntase Gene (CYP11B2) Promoter Polymorphism as a Risk Factor for Ischemic Stroke in Tunisian Arabs. Journal of ReninAngiotensin-Aldosterone System, 2010; 11:180.

5. World Health Organization, 2006. STEP Stroke Surveillance. Available from: http://

www.who.int/entity/chp/steps/Section 1_Introduction.pdf [Accessed 2 October 2013].

6. Davenport R \& Dennis $M$. Neurological Emergencies: Acute Stroke. J Neurol Neurosurg Psychiatry, 2000; 68: 277288.

7. Kelompok Studi Serebrovaskuler Perhimpunan Dokter Spesialis Saraf Indonesia, 2004. Guidelines Stroke 2004. Perhimpunan Dokter Spesialis Saraf Indonesia. [cited 5 Januari 2012]. Available from: 
http://www.scribd.com/doc/12700451 5/guideline-stroke-perdossi-2004-full.

8. Ness J, Aronow W S, Ahn C. Risk Factors for Ischemic Stroke in Older Persons in an Academic Hospital Based Geriatrics Practice. J Preventive Cardiology, 1999; 3:118-120.

9. Ardelt A A. Acute Ischemic Stroke. In: Harrigan M. R \& Deveikis J. P. ed. Handbook of Cerebrovascular Disease \& Neurointerventional Technique. New York: Humana Press, 2009; 571-
605.

10.Furie K L. Guidelines for the Prevention of Stroke in Patients With Stroke or Transient Ischemic Attack. A Guideline for Healthcare Professionals From the American Heart Association/ American Stroke Association. J Stroke, 2010. [cited 5 Januari 2012]. Available from: http://stroke.ahajournals.org/content/e arly/2010/10/21/str.0b013e3181f7d04 3.full.pdf. 